\title{
III. Additional memoir upon living and fossil elephants
}

\section{Cuvier}

To cite this article: M. Cuvier (1808) III. Additional memoir upon living and fossil elephants , Philosophical Magazine Series 1, 30:117, 15-25, DOI: 10.1080/14786440808563759

To link to this article: http://dx.doi.org/10.1080/14786440808563759

曲 Published online: 18 May 2009.

Submit your article to this journal ๘

Џ Article views: 2

Q View related articles $\asymp$ 
$u$, we shall have by hypothesis, $\mathrm{A}: \mathrm{B}:: u: \mathrm{V}$, o: $\mathrm{AV}=$ $B u$, therefore $\frac{A V-B u}{A+B}=0$. This being done, snce the bodies are supposed to be in motion, the one fron top to bottom, and the other vice versâ, it is evident that he first member of this equation is the vertical velocity of the centre of gravity of the system: thus this centre of gravity will not descend, and therefore by the preceding position there must be an equilibrium.

[To be continued.]

III. Additional Memoir upon living and fossil Elephants. By M. Cuvier.

[Concluded from vol. xxix. p. 254.]

Article VII.

Comparison of the Crania of the Elephant of Indic and that of Africa-External Characters taken from ihe EarsParts of the Cranium susceptible of Variation $n$ one and the same Species.

I HAD the good fortune to be the first to remark, in 1795 , the distinctive characters presented by the crania of the two elephants, and which are so much the more ineresting, as they may be applied to living, or entire individıals, without being obliged to examine their jaws*. I was able to recognise them at first only by the comparison of a cranium of each species; I have now verified these olservations by inspecting seven real crania, (five of which are Indian, and two African,) and several drawings.

When these crania are separated from thir lower jaws and placed upon the grinders, and upon the edges of the alveoli of the tusks, the zygomatical arcades are nearly horizontal in both species.

If we next view them laterally, what is very striking is,

- Plate II. was long ago engraved from my own druwings. I gave a proof impression of it several years ago to $M$. Wiedeman of Brunswick, who copied it into his Archives de Zootomie, tome ï. cah. I, pl, h-Tue Aurror. 
that th: summit of the head is almost round in the African elephart, and that it rises in the Indian elephant into a kind of doulle pyramid.

Thissummit answers to the occipital arcade of man and other animals, and is so high in the elephant merely for the purpose of giving to the occipital face of the cranium a sufficient extent for a cervical ligament and occipital muscles, proportionate to the weight of the enormous mass they have to support.

This difference in the form of the summits proceeds from the difference in the inclination of the frontal line, which retreats much further in the African elephant, where it forms with the occipital line an angle of $115^{\circ}$, than in the Indian elephant, where it makes an angle of $90^{\circ}$ only.

From this come the principal differences of the profile, such as, 1st, The proportion of the vertical height of the head at the distance from the end of the bones of the nose to the occipital condyles, which are nearly equal in the African elephant, (being as 33 to 32, ) and the first of which is nearly one-fourth larger in the Indian elephant (being as 24 to 9). $2 \mathrm{~d}$, The proportion of the distance from the edges of the alveoli of the tusks at the summit to a line which is perpendicular to it and goes from the end of the bones of the nose to the anterior edge of the occipital hollow. The irst of these lines is almost double that of the other in theindian elephant (being as 26 to 14). It is little less than ont-fourth larger in the African elephant (being as 21 to 16).

Besides these in the proportions, there are also differences in the contoul: 1st, The front of the Indian elephant is hollowed into a sinking and concave curve; that of the African elephant is on the contrary a little convex. 2d, The sub-orbitary hole is larger in the Indian jelephant. In the African, it resembles a channel rather than a simple bole. $3 \mathrm{dly}$, The temporal hollow is rounder in the African elephant; and the apophysis, which distinguishes it from the orbit, is thicker than in that of India, in which this hollow has an oval contour.

When 
When observed by their front view, these crania also present very remarkable differences.

1st, The greatest length of this front, taken from the summit to the edge of the alveolus, is at its greatest breadth, taken between the post-orbitary apophyses of the frontal bone, as 5 to 3 in the Indian elephant, and as 3 to 2 in the African elephant.

$2 d$, The aperture of the nose is nearly in the middle of the face in the Indian elephant; it is one-fifth further removed from the edge of the alveolus than from the summit of the head in the African elephant.

When seen from above, these crania differ, particularly by their zygomatical arcades; they are more salient in the African than in the Indian elephant.

When we look at them behind, we are struck with new characters :

1st, The height of the wings of the sphenoidal bones, forms in the Indian elephant more than three-fourths of that of the occipital surface, while in the African elephant it scarcely forms one half.

2d, In the African elephant the posterior extremity of the zygonatical arcades is nearly on a level with the occipital condyles; in the Indian elephant it is much lower.

$3 \mathrm{~d}$, The occiput is terminated in the upper part in the African elephant, by a semi-elliptic curve, and its base is formed by two lines in a very open angle. In the Iudian elephant, the sides are in convex arcs, and the upper part of the arc is slightly concave.

The grinders are placed in both species upon two lines which converge before; they differ only by their lamina, as we have said above.

Most of the characters we have described, contributing to the general configuration of the head, are sensible externally; there is one still more prominent, and which may distinguish the two species at the first glance. I think I was the first to remarl it: it consisis in the size of the ears.

The Indian elephant has middling-sized ears :-they are so large as to cover the whole shoulders in the African elephant.

$$
\text { Vol. 30. No. 117. Feb. } 1808 .
$$


I made myself certain of the first point: Ist, In three elephants which I saw alive; and I dissected two of them : two were from Ceylon, and the third from Bengal. ad, In two other individuals which I saw in a state of preservation. $3 \mathrm{~d}$, In all the figures well known to belong to the Indian species, particularly those of Buffon, Blair, and Camper. 4th, In the figure of a foetus elephant from Ceylon, described by Zimmermann, in a quarto volume upon the subject *.

Upon the second point, I have the following proofs: 1st, The elephant from Congo, dissected by Duverney. We may see its figure in the Mémoire pour servir a l'Hist. des Anim. par. iii.; and I am sure that the ear is not exaggerated, for it is still preserved in the Museum, and 1 have seen and examined it.

2d, An ear preserved in the king of Deumark's cabinet, and taken from an elephant killed at the Cape of Good Hope by captain Magnus Jacobi, in 1675. It is three feet and a balf long, and two feet and a balf broad $\dagger$.

3d, A young African elephant in our Museum; its ears, although shrivelled up by being dried, are still as large as its head.

4th, An embryo elephant from Africa, in our Museum.

5 th, All the well-known figures of the African elephants.

From these characters we may be assured from what species those figurcs have been drawn the origin of which is unknown, or such as are to be seen on antient monuments.

Thus that of Gessner $\ddagger$, copied by Aldrovandus $\S$, is an African elephant. That of Valcutine \#, copied by Labat 9 , and altered by Kolbe**, is equally so.

On the contrary, those of Jonston + , which are very good, and which have served as a mudel to those of Hartenfeis

* Erlang, 1783, in 4to. †Oliger Jacobxus, Mus. reg. Dan. 1697, ful. p. 3. † Quad. p. 577. \$ Quad. lii\}. i. p. $465 . \quad \|$ Amphithéâtr. Zoot. tab. i. f. S. Afr. Occ. iii. p. 271 . ** Relation du Cap. trad. Fr. in 12mo, tome iii. p. 11. t+ Quadr. tab. vii, viii, et ix. 招 Elephantograph, curios. passim.

$\$ \S$ Athiop. lib. i. cap. 9. 
his; that of Neuhof*, the tusks of which are too high; that of Edwards $\uparrow$, the head of which is too round, because it is taken from a young subject, to which it was necesssary to add tusks, are all Indian elephants.

The two figures in Bufion $\ddagger$, copied by Schreber $\S$, and by Alessandrill, are the two sexes of the Indian species.

Mayer gives a rolerable figure of a male dauntelah, (vorstell. allerh. thiere, i. pl. lxix.;) but the skeleton (ib. Ixx.) is copied from Blair, without any correction.

The elephant foetus preserved in the East India Company's house at Amsterdam, and represented by Seba, (tome i. pl. cxi.) is also of the Indian species.

The limits between the Indian and African species was already distinctly enough traced with respect to the various parts of the head, and without having accasion to resort to the other characters, which we shall point out by and bye, and which are supplied by the number of the nails, and the forms of various bones of the limbs ; but before being able to apply with certainty the osteological characters of the cranium to the fossil elephant, we must determine what are the variable parts of one individual from the other, in one and the same species. I have therefore subjected my Indian crania to a comparison with each other; and I did the same with my African ones.

The latter presented me with scarce any appreciable difference.

As to the former, I found some with respect to the occiput and the alverit of the tusks.

The occiput is nore sweiled in every direction in the former than in the latter, without regard to the length of the tusks.

The alveoli of the tusks of the dauntelah are a little more oblique in front; those of the moakna are a little straighter towards the bottom.

The latter are a little smaller, but by no means so much so in the proportion of the tusks themselves. What is

* Ambass. Orient. Descr. Gen, de la Chine, p. 94. †Av. 2Q1, f.1. f Hist. Nat. xi. Pl. i. ei Suppl. §Quad, ki. tab. 78. \|Quad. i. Pl. ii. B 2 deficient 
deficient in the size of the tusks is compensated by a greater thickness in the osseous substance of the alveolus. The reason is, that the alveolus, serving as a base and a socket for the muscles of the proboscis, could not shrink as well as the tusks, without the proboscis lusing the strength and thickness which is necessary for it.

Lastly, There is a little variety in the length of the alveoli; and, what is very renuarkable, even without any reference with that of the tusks. Our large mookna skeleton has them longer than our two dauntelahs, although its tusks are the smallest of all. 'To conclude,-this increase in length does not exceed an inch.

It could not be considerable without the organisation of the proboscis being esseutially changed, because the muscles of its lower part are inserted under the lower edge of the alveoli of the tusks, and those in the upper part are in the front, above the bones of the nose. The base of the proboscis has therefore necessarily for its vertical diameter the distance between these two points; and if the alveoli are prolonged beyond a certain measure, the proboscis would assume a monstrous size.

It is very important to notice this article, because it furnishes the most distinctive character of the fossil elephant.

If we compare together the small number of figures of elephants' skulls found in the works of naturalists, I do not think any stronger differences will be found than those I have mentioned.

The table annexcel to the succecding article expresses these differences by numbers.

A celebrated author has supposed a difference betwcen the crania of males and females, which we have not mentioned, but he has been deceived by simple external appearances.

Our small mookna from Ceylon had, at the root of the proboscis, a very perceptible protuberance, which the female had not. M. Faujas, imagining that this protuberance belonged to the osseous parts, has represented these two heads in Pl. xii. of his Essais de Geologie. "In order to avoid," he says, p. 238, "falling into an error, when we. 
find the heads of a male and female fossil elephant, we must not mistake them for two different species."

Dissection has shown us, however, that this protuberance was only produced by two cartilages peculiar to elephants, which cover the entrance of the canals of the probuscis into the osseous nostrils.

These cartilages were a little more swelled in this indivilual than in the others.

It is not even a character common to all males. The datuntelah of Bengal had it not.

The same letrned geologist has given to his figures much larger tusks than these two individuals had in reality, "In order," he says, p. 269 , "to make those understand, who never saw an elephant, the manner in which these auimals carry their tusks." It was not necessary, however, to give large tusks to the female, which never has any in the Indian species.

\section{Article VIII.}

Examination of the Cranium of the fossil Elephant.

The cranium was very cellular; the osseous laminæ composing it were too thin to be preserved in the fossil state: they are therefore found in innumerable fragments; but three only are mentioned as being in a state of good preser. vation, and the most entire of the whole wants a part of the occiput.

They belong to the Petersburgh Academy*; the best was found upon the banks of the river Indigirska, in the most castern and coldest part of Siberia, by the learned and intrepid Messerschmidt of Dantzick, who gave a drawing of it to his countryman Breynius, The latter had it engraved at the end of a memoir he inserted in the Philosophical Transactions $t$, and to this day it is the only public document we have upon this part of the skeleton of the fossil elepnant.

I have copied the figure of Breynius in Pl. ii. fig. 1, besides the African and Indian crania; and $I$ have reduced the three to the same size nearly, in order to facilitate their

* Pallas, Nov. Com. Petrop. xïi. 
comparison. The first glance shows that the fossil elephant resembles, in its cranium as well as in its teeth, the Indian species rather than any other.

Unfortunately the drawing is not correct enough for an exact comparison, and it is not made upon a well-determined projection. The part of the alveoli, that of the condylon for the lower jaw, and the anterior edge of the temporal hollow, and of the orbit, are seen a little obliquely behind, while the occiput and the grinders are in a rigorous profile.

We see distinctiv enough, however, a striking difference in proportion in the extreme length of the alveoli of the tusks. It is treble what it would be in an Indian or African cranium of the same dimensions; and the triturating surface of the grinders prolonged, in place of meeting the alveolary edge, would intersect the tube of the alveolus at one-third of its length.

This difference is so much the more important as it agrees with the form of the lower jaw, as we see below; and, as we have already said, it would of necessity prorluce another conformation in the probuscis of the fossil elephaut; for where the sockets of the muscles of the proboscis were the same, $i . e$. the upper part of the nose and the lower edge of the alveoli of the tusks; in this case the base of that organ was three times larger in proportion than in our living elephants; or rather the sockets of the muscles were different, and à fortiori its totd structure was different.

If we could trust entirely to drawings, we should also find, 1st, That the zygromatic arcade is differently figured; 2d, That the posi-orbitary apophysis of the frontal bone is longer, more pointed, and more crooked; 3d, That the tubercle of the lacrymal bone is much larger and more salient.

As to the absolute size of the fossil cranium, compared with our living crania, we may form an idea of it from Plate iv. fig. $9,10,11$, where I have represented the three crania in front, and upon the same scale.

We may form a still more correct idea of their size from the following table, in which I have collected the dimensions of all the crania with which I am acquainted.

Table 
PRILIPHANTS. PH. VHA.

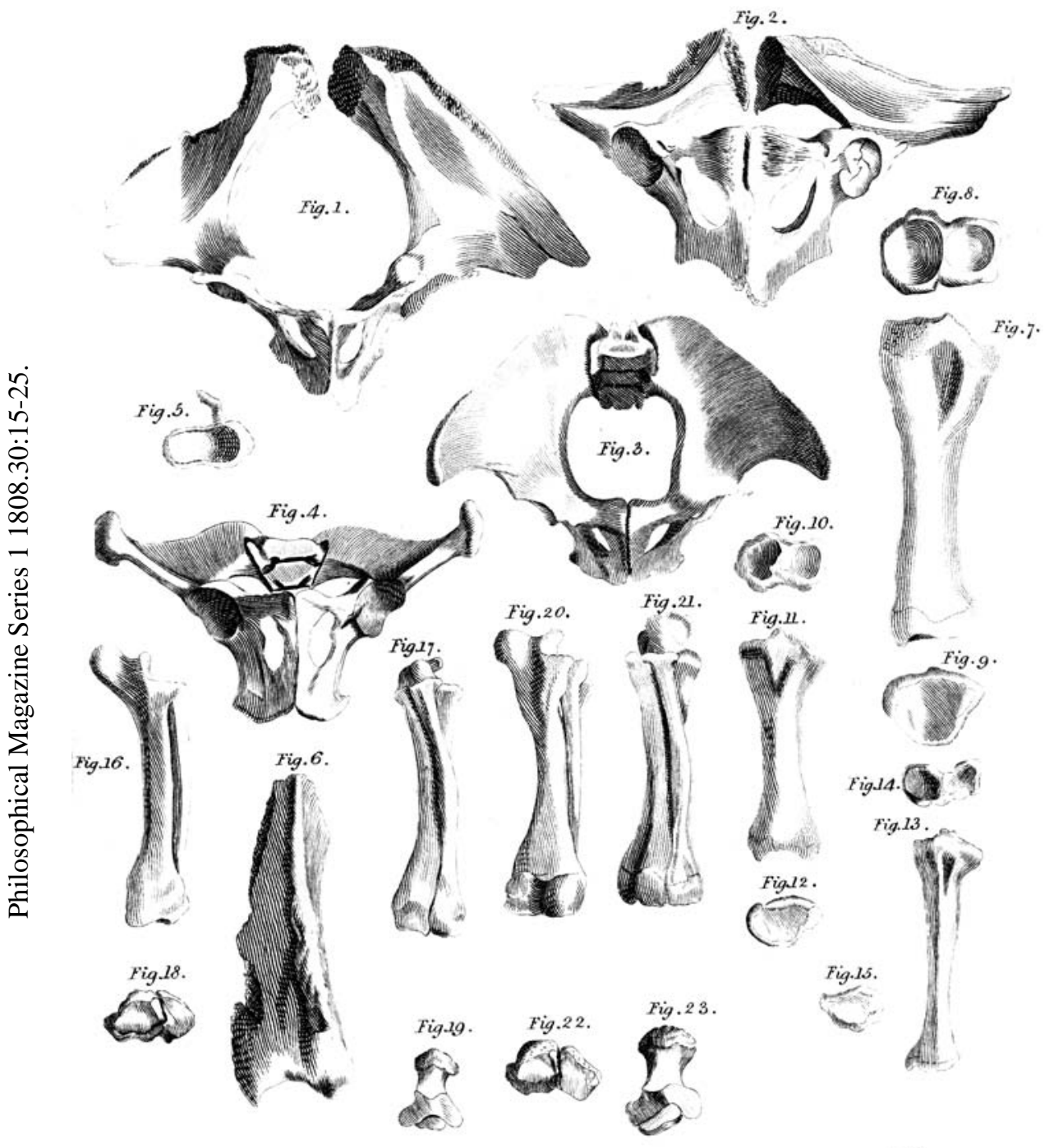


Memoir ufon living and fossil Elephants.

\begin{tabular}{|c|c|c|c|c|c|c|c|c|c|c|}
\hline 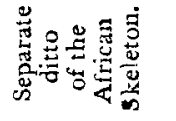 & & $\begin{array}{l}0 \\
0 \\
0 \\
0\end{array}$ & $\begin{array}{l}n \\
03 \\
0 \\
0\end{array}$ & $\begin{array}{l}5 \\
0 \\
0\end{array}$ & $\begin{array}{l}b \\
5 \\
3\end{array}$ & $\begin{array}{l}0 \\
0 \\
0 \\
0\end{array}$ & $\begin{array}{l}\overrightarrow{10} \\
\text { की } \\
0\end{array}$ & & $\begin{array}{l}\stackrel{8}{\sharp} \\
0\end{array}$ & $\stackrel{8}{8}$ \\
\hline 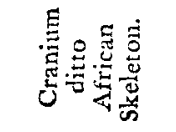 & & & $\begin{array}{l}0 \\
8 \\
0 \\
0\end{array}$ & $\begin{array}{l}\infty \\
\dddot{m} \\
+\end{array}$ & $\begin{array}{l}0 \\
0 \\
4 \\
3\end{array}$ & \begin{tabular}{l} 
a \\
\multirow{\infty}{*}{} \\
$\infty$ \\
$\dot{0}$
\end{tabular} & $\begin{array}{l}\vec{n} \\
\dot{0}\end{array}$ & & 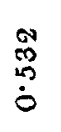 & $\begin{array}{l}8 \\
0 \\
+ \\
0\end{array}$ \\
\hline 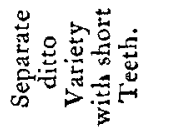 & & ठ் & $\stackrel{ \pm}{\stackrel{*}{\infty}}$ & $\begin{array}{l}8 \\
0 \\
0\end{array}$ & & $\begin{array}{l}0 \\
0\end{array}$ & סे & & $\begin{array}{l}8 \\
\ddot{n} \\
\dot{0}\end{array}$ & $\stackrel{\infty}{\infty}$ \\
\hline 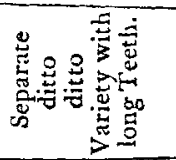 & ? & $\frac{2}{6}$ & $\begin{array}{l}\vec{H} \\
\overrightarrow{0} \\
\dot{0}\end{array}$ & 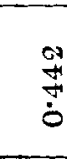 & & $\frac{9}{0}$ & $\begin{array}{l}\infty \\
\dot{0}\end{array}$ & & $\stackrel{n}{\ddot{0}}$ & $\stackrel{n}{\square}$ \\
\hline 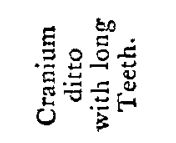 & 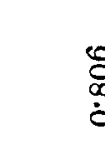 & $\begin{array}{l}8 \\
0 \\
0 \\
0\end{array}$ & $\begin{array}{l}m \\
\stackrel{n}{0} \\
\ddot{0} \\
\dot{0}\end{array}$ & $\stackrel{0}{\dot{H}}$ & & $\frac{12}{2}$ & $\dot{\overrightarrow{5}}$ & & $\begin{array}{l}\overrightarrow{4} \\
\dot{0}\end{array}$ & $\begin{array}{l}20 \\
0 \\
0\end{array}$ \\
\hline 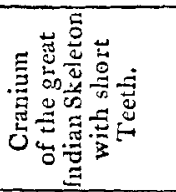 & & 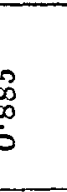 & $\begin{array}{l}\hat{\infty} \\
\ddot{0}\end{array}$ & $\begin{array}{l}\dot{8} \\
\dot{0}\end{array}$ & 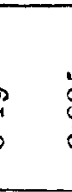 & $\begin{array}{l}\stackrel{0}{0} \\
\infty \\
0\end{array}$ & $\dot{0}$ & & $\begin{array}{l}n \\
\vdots \\
0\end{array}$ & $\frac{5}{0}$ \\
\hline 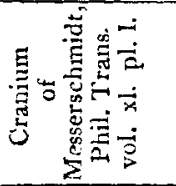 & & $\frac{0}{\infty}$ & $\begin{array}{l}: \\
:\end{array}$ & $\begin{array}{l}0 \\
0 \\
0\end{array}$ & & ! & : & & $\begin{array}{l}\infty \\
\infty \\
\infty \\
0 \\
0\end{array}$ & $\vdots$ \\
\hline 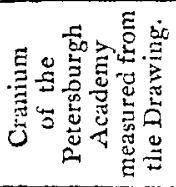 & & 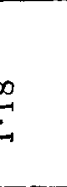 & $\stackrel{0}{\dot{0}}$ & & : & $\begin{array}{l}\dot{0} \\
\dot{0}\end{array}$ & : & & : & $\vdots$ \\
\hline & 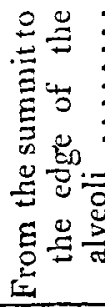 & 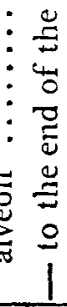 & 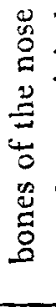 & 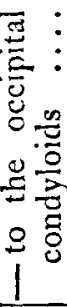 & 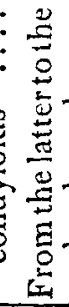 & 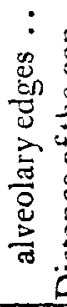 & 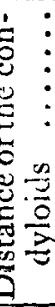 & 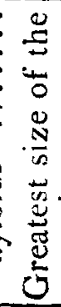 & $\begin{array}{l}\vdots \\
\vdots \\
\Xi \\
\vdots \\
\vdots \\
\vdots\end{array}$ & 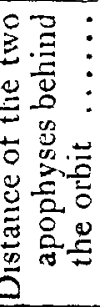 \\
\hline
\end{tabular}


But in order to infer from any one of these crania the dimensions of the animal to which it belonged, it is not necessary to refer to its first dimensions, into which the excessive length of the alveoli of the tusks enters; these only should be taken into consideration which are really homolingous.

Now, by comparing them with those of the cranium of our Indian skeletons of the mookna and comerea, we find that the fossil animal must have been nearly twelve feet high. A comparison with the skeletons of the Indian dauntelah and meyhée would give a little nore to the fossil.

As soon as I was asquainted with this drawing of Messerschmidt, and added to the differences it presented those I had myself observed in the lower jaw and in some isolated teeth, I no longer supposed that the fossil elephants were of a different species from those of India.

This idea, which I first announced in a memoir to the Institute, opened quite new views to me upon the theory of the earth; a hasty glance at other fossil bones induced me to presume every thing I have since discovered, and determined me to devote myself to the assiduous researches and tedious labours in which I have been occupied these ten years past.

I ought therefore to acknowledge, that it is to this drawing, buried as it were in the Philosophical Transactions for seventy years, that the public are indebted for all those works upon which I set so high a value.

I must not dissemble, however, that the characters it presented me required to be confirmed by some other specimen, in order that they might not be considered as the same species, and in spite of their agreement with those of the lower jaw, I was happy to find a drawing of another cranium.

I applied to the Perersburgh Academy; and this illustrious body, to which I now belong, complied with my wishes, with a generosity worthy of a Society to which science is so much indebted.

The Academy ordered a superb coloured drawing of the natural size to be transmitted to me of another fossil cranium from Siberia, in their collection also. It was accompanied 
with a drawing of the lower jaw of a cranium of a rlinoceros, in two positions. In these drawings I found a con-* firmation of what I had conceived from seeing Messerschmidt.

The cranium, which served for the model, is not so complete. The grinders, and a part of their alveoli, are wanting, as well as the middle part of the zygomatical arcade. Nothing characteristic is however missing: there is the same length and the same direction of the alveoli ; the same size of the lacrymal tubercle, and the same general form : every thing in fact convinces us that the fossil skulls partake of the same characters.

I have carefully engraved this fine drawing in my Plate viii. fig. 2.

The parallelism of the grinders is a difference which may be established independently of the drawings of Messerschmidt or of the Petersburgh Academy.

M. Jæger assures me of the same fact, with reference to a portion of a cranium in the Stutgard cabinet, and which may be found in my Plate iv. fig. 4 : another piece, drawn by Peter Camper, shows the same character*. I have copied his figure, Plate iv. fig. 3, and I have placed beside it fig. 1 and 2, those of Indian and African crania, seen from below, in order to show the more remarkable convergency of their front teetb.

We have in our Museum a portion of the occiput and of the temporal bone of a fossil elephant, brought from Siberia by the astronomer Delisle, which afforded me an opportunity of comparing these parts more closely than the others, of which I had drawings only; but I found some very trifling differences; I have given a back view of it in fig. 7, and a lateral one in fig. 8 , of Plate iv. This specimen belonged to an elephant ten feet high.

* Mem. de Haarlem, tom. xxiii. Pl.D. 


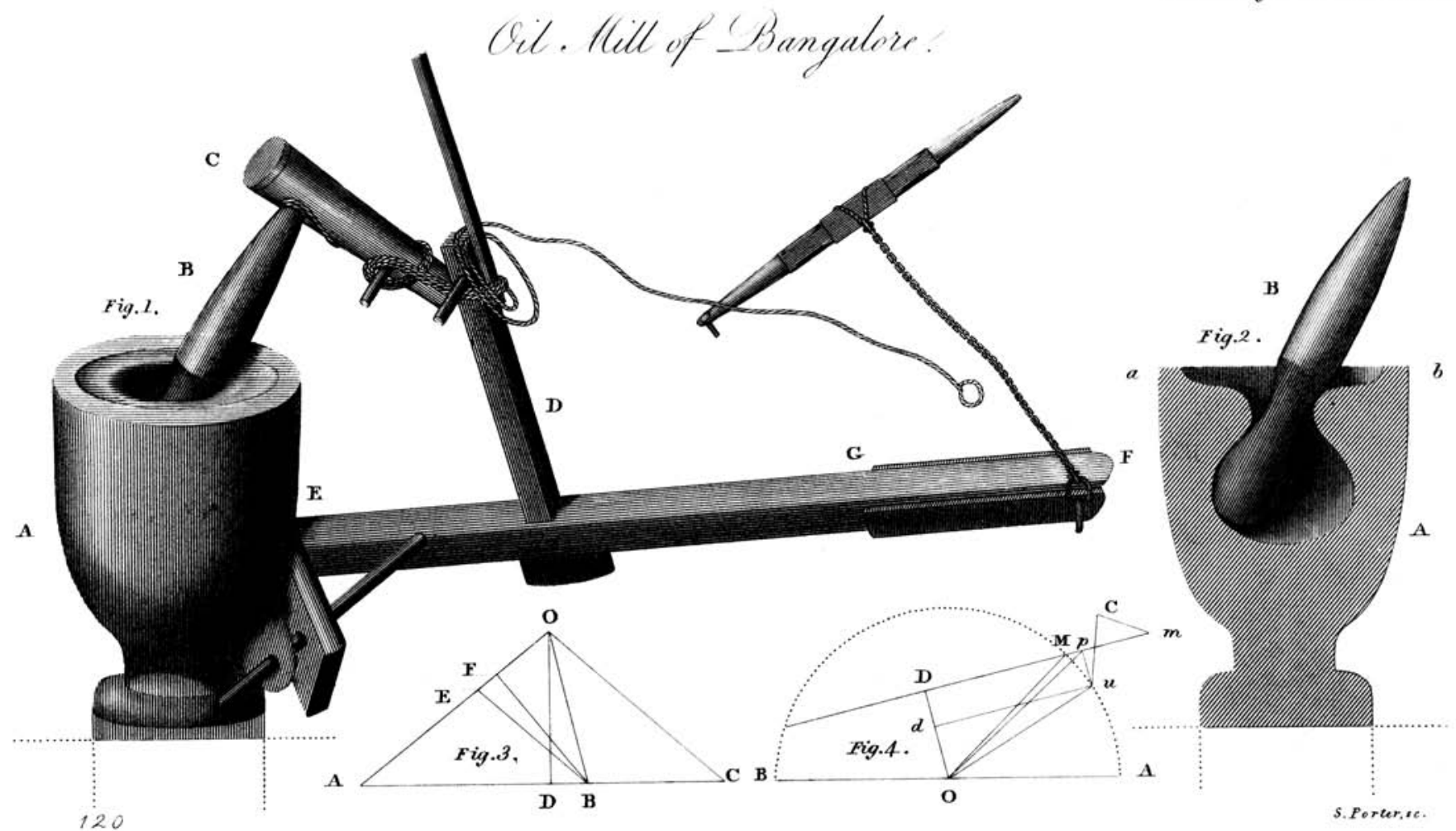

